\title{
Labor Market Structures and the Sacrifice Ratio*
}

\author{
Christopher Bowdler \\ Department of Economics and Oriel College, University of Oxford. \\ Email: christopher.bowdler@economics.ox.ac.uk \\ Luca Nunziata \\ University of Padua, IZA Bonn \\ Email: luca.nunziata@unipd.it
}

\begin{abstract}
Using OECD panel data for 1961 - 2000 we provide evidence that the output cost associated with disinflation (the sacrifice ratio) decreases with coordination between wage-setters in the labor market. The relationship holds for alternative measures of labor market coordination and after controlling for standard sacrifice ratio determinants. The sign of the relationship is robust across alternative definitions of the sacrifice ratio, but its statistical significance varies. Our results also indicate that more stringent employment protection laws increase sacrifice ratios, but the effect is not significant at conventional levels. We provide explanations for our findings based on the speed of nominal wage adjustment in New Keynesian models.
\end{abstract}

JEL Classification: E30.

Keywords: sacrifice ratio, labor markets, wage coordination, employment protection.

* We thank Tony Caporale for supplying data on the political stance of governments in the OECD during the post-war period and four anonymous referees for very helpful comments. 


\section{Introduction}

International differences in the output cost of disinflation (the sacrifice ratio) have been the focus of renewed interest in monetary economics since the study by Ball (1994). Recent empirical contributions have investigated a wide range of potential sacrifice ratio determinants. The impact of trade openness is examined by Temple (2002), Daniels, Nourzad and VanHoose (2005) and Bowdler (2009), and the effect of current account and capital account restrictions is investigated by Razin and Loungani (2007). Other studies focus on the credibility of macroeconomic policy during disinflation. In particular, the sacrifice ratio has been shown to decrease with the probability agents assign to successful inflation reduction (Boschen and Weise, 2001), the presence of governments from the political right (Caporale and Caporale, 2008) and the existence of an inflation targeting regime (Goncalves and Carvalho, 2009). On the other hand, Jordan (1997) finds that central bank independence increases the sacrifice ratio and this result is confirmed by Daniels et al. (2005). A related line of research has provided new procedures for measuring sacrifice ratios and evidence concerning the dependence of those sacrifice ratios on a range of factors, including the inflation regime prior to disinflation, see Zhang (2005), Hofstetter (2008) and Senda and Smith (2008). In this paper we provide evidence that labor market structures influence international differences in sacrifice ratios, building on ideas that have often been discussed in the literature but which have rarely been tested.

Disinflation episodes are often initiated by periods of tight fiscal and monetary policy. Ultimately, the success of such policies depends on a decrease in the inflation expectations of priceand wage-setters. Lower inflation expectations provide a basis for lower nominal wage growth, which helps to lock in inflation reductions. The importance of wage-setting to inflation dynamics is recognized in both macroeconomic policy-making and research. During the 1960s and 
1970s many governments employed direct wage controls as a tool of anti-inflation policy, see for example Nelson (2005). In recent research Olivei and Tenreyro (2007) utilize information on the timing of wage negotiations to explain within year variation in the trade-off between inflation and output.

The idea that we emphasize is that labor market structures can affect the speed at which nominal wage growth moderates during disinflation episodes and thereby play a role in determining the sacrifice ratio. The starting point is that labor markets are imperfectly competitive, such that wage-setters decide the precise timing of wage moderation after disinflation policies are initiated. This behavior is a feature of New Keynesian models in which price- and wage-setting is staggered and agents are averse to relative price and wage changes, see Ball and Romer (1991) for a model that captures these effects and Taylor (1983) for discussion in the context of labor markets. The factors that determine the length of time until wage moderation will be critical in setting disinflation costs - delays will thwart disinflation, prompting larger output losses. When labor market laws afford considerable protection to those in employment, e.g. through restrictions on firing by firms, wage-setters may choose to delay wage moderation because the chances of job losses are limited, and dominated by the benefit from higher real wages. We therefore hypothesize a positive relationship between the sacrifice ratio and the strictness of employment protection arrangements.

In contrast, when labor markets are centralized and interactions between firms and wagesetters highly coordinated, for example in Scandinavian countries, wage moderation can be implemented more rapidly. The reason is that when unions negotiate from an aggregate perspective they are more likely aware that wage moderation for one set of workers is occurring alongside economy wide moderation, leaving relative wages unaffected. As a result the relative wage concerns that can frustrate nominal adjustment are absent and disinflation can proceed at 
lower output cost. ${ }^{1}$

Our contribution is to investigate the relationship between labor market structures and sacrifice ratios using a detailed panel dataset on differences in employment protection laws, unionization rates and the degree of labor market coordination in 18 OECD countries, and a baseline sample of 76 disinflation episodes obtained from Ball (1994) and Bowdler (2009). The results show that higher levels of coordination in wage bargaining are associated with statistically significant reductions in the sacrifice ratio. More stringent employment protection laws are associated with larger sacrifice ratios, though the statistical significance of that relationship is weaker than that based on labor market coordination. Building on previous work on the effects of labor market coordination on macroeconomic outcomes (Calmfors and Driffill, 1988, Daniels, Nourzad and VanHoose, 2006) we investigate an inverse U-shape relationship between coordination and the sacrifice ratio, and find weak evidence for a non-linearity of that kind. In an important extension of our baseline results, we examine sacrifice ratios from Senda and Smith (2008), calculated using the assumptions regarding trend output during disinflations proposed by Zhang (2005) and Hofstetter (2008), which are different to those employed by Ball (1994) and Bowdler (2009). The effects of labor market coordination and employment protection are qualitatively similar to those in our baseline results, but significant at confidence levels of just $10 \%, 15 \%$ or lower. On the other hand, our results are generally robust to alternative extensions of our methodology such as the use of different measures of coordination and employment protection, the use of fixed effects and time dummies and the exclusion of outlier observations.

\footnotetext{
${ }^{1} \mathrm{~A}$ review of the channels linking labor market structures and the speed of nominal wage moderation is provided in Calmfors (2004). The other channels discussed include the idea that coordinated structures reduce the average duration of wage contracts, relative to decentralized structures, because an externality (greater aggregate nominal rigidity) is neglected in the latter case, leading to inefficient contracts, see Ball (1987).
} 
Our paper contributes to a substantial literature on labor market structures and macroeconomic outcomes. Bruno and Sachs (1985) and Calmfors and Driffill (1988) represent important early contributions. More recently, Thomas (2001) shows that nominal wage growth is more responsive to unemployment under highly centralized wage bargaining systems (though it is not necessarily more responsive to productivity growth, or input price shocks) and Nunziata (2005) shows that real wages are more responsive to unemployment under coordinated bargaining systems. In his original study of sacrifice ratios, Ball (1994) found a negative and marginally significant effect from the Bruno and Sachs (1985) indicator of wage flexibility. This index pools discrete measures of the duration of wage contracts, the synchronization of wage negotiations and the degree of indexation of wage contracts. ${ }^{2}$ In section 3 we discuss how our results relate to this evidence. Finally, in investigating the effect of central bank transparency on the slope of the Phillips curve (which is related to the sacrifice ratio), Chortareas, Stasavage and Sterne (2003) use labor market coordination as a control. The coordination index is positively correlated with the speed of inflation adjustment, consistent with the argument that we have described. However, the Phillips curve proxies are available for a sample of just 21 countries, precluding systematic investigation of the effects of other labor market institutions.

The structure of the paper is as follows. In section 2 the measurement of the sacrifice ratio, labor market structures and other variables is discussed, and the basic form of the regression models is presented. In section 3 the results from a range of regression specifications are interpreted in terms of the main hypotheses proposed in this introduction. Tests for non-linear relationships are presented, and various robustness exercises are discussed. Section 4 concludes with a summary of the paper.

\footnotetext{
${ }^{2}$ Ball obtained a similar result using a measure of the speed of wage adjustment estimated from time series regressions.
} 


\section{Data and Methodology}

The sacrifice ratio is defined by Ball (1994) as the ratio between total output losses and the change in trend inflation over the course of a disinflation (a disinflation is a period during which trend inflation falls by more than 1.5 percentage points from peak to trough). Total output losses are calculated as the sum of annual percentage deviations of real GDP from a straight line connecting output in the year of an inflation peak to output in the year after an inflation trough. Trend inflation in year $t$ is an average of the annual rate of consumer price inflation recorded in eight quarters, namely the four quarters of year $t$, the last two quarters of $t-1$ and the first two quarters of $t+1$. Ball calculates sacrifice ratios for 65 disinflation episodes in 19 OECD countries observed for $1961-88$.

This sample is expanded through adding disinflations that have occurred since 1988 for each of the 19 countries studied by Ball. The source for additional observations is Bowdler (2009), who calculates post-1980 sacrifice ratios using the procedure introduced by Ball. In the case of disinflations that occurred in the 1980s, estimates of the sacrifice ratio are available from both the original Ball study and the more recent source. In some instances the two studies differ slightly in terms of the dating of disinflation episodes, probably due to the effects of data revisions, but in general there is a strong concordance between the two sets of estimates for the period of overlap, see Bowdler (2009) for discussion. In order to maintain full comparability with other papers in the literature, the Ball estimates of the sacrifice ratio are used through 1988, and observations from the alternative source are added post $-1988 .{ }^{3}$ A similar strategy is followed by Caporale and Caporale (2008), who augment Ball's sample using post-1988 estimates of the sacrifice ratio from Andersen and Wascher (1999). Although there are some differences across

\footnotetext{
${ }^{3}$ The 1986-92 disinflation in New Zealand reported in the Bowdler (2009) sample is not used because it overlaps with the final disinflation that Ball reports for New Zealand.
} 
the sacrifice ratios identified by Andersen and Wascher and Bowdler for the post-1988 period, in our results we are able to reproduce the main findings from Caporale and Caporale (2008), suggesting general agreement between the two sources. ${ }^{4}$ One advantage of extending the sample using observations from Bowdler is that sacrifice ratios are calculated using output losses relative to local linear trends and are therefore directly comparable with the original Ball data, whereas Andersen and Wascher use output losses relative to trends calculated by the OECD.

In order to explore the relationship between the sacrifice ratio and labor market structures, we estimate regressions of the form

$$
S A C_{i}=\alpha+\beta C O I B_{i}+\gamma E P_{i}+\zeta T U_{i}+\gamma^{\prime} \mathbf{X}+\varepsilon_{i}
$$

where $i$ denotes a disinflation, $S A C$ is the sacrifice ratio in percentage points, $C O I B$ an index of labor market coordination, $E P$ an index of employment protection and $T U$ a measure of the importance of trade unions in the labor market. The vector $\mathbf{X}$ comprises controls that we discuss below, and $\varepsilon$ is an error term. All labor market variables are from the year in which disinflation commences. ${ }^{5}$ A key issue is the measurement of labor market structures. In the case of $C O I B$ we use an index of the degree of coordination in wage bargaining due to Kenworthy (2001). This is a de jure measure that summarizes information on labor market characteristics that are believed to influence the coordination of wage-setting, e.g. the number of unions in the bargaining process, the fraction of the workforce whose wages are determined through bargaining and the degree to which minor players in the market follow the agreements reached by larger

\footnotetext{
${ }^{4}$ Andersen and Wascher identify a disinflation for Germany in the 1990s that is not identified by Bowdler, whilst Bowdler identifies two disinflations for Italy during the 1990s when Andersen and Wascher identify just one.

${ }^{5}$ Using averages for the years spanned by a disinflation gives very similar information because of the smoothness of the indicators through time.
} 
unions. As discussed in Kenworthy $(2001,2003)$ the index pools information from other studies that measure coordination in wage-setting. We therefore interpret it as a summary measure of the dozen or so de jure coordination measures that could have been used - Kenworthy (2003) shows that his indicator is highly correlated with other available measures. The index increases in the degree of coordination and varies across countries and time, from 1 (e.g. the U.S.) to 5 (e.g. Japan). Relevant summary statistics for all variables are presented in table 1.

It is important to note that coordination in wage-setting extends the concept of centralization in wage-setting, which has often been analyzed in the literature. Greater centralization of labor markets, so that they are dominated by a small number of unions, is one means of achieving coordination, but others include guidance of decentralized systems by market actors such as union and employer confederations, dominant unions or government sponsored forums (Kenworthy, 2003). As any one of these mechanisms may facilitate wage moderation during disinflation episodes, it is coordination in wage-setting that we use to explain variation in sacrifice ratios, rather than centralization of wage-setting. See Soskice (1990) and Flanagan (1999) for a discussion of the importance of this distinction for empirical work on labor market configurations and macroeconomic outcomes.

The measure of employment protection, EP, is taken from Nickell et al. (2005). It increases in the strictness of employment protection legislation and takes values in the range $0-2$. The maximum value occurs for countries such as Italy, where laws regulating the firing of workers and the rights of part-time workers are judged most restrictive. The series exhibits some time variation, but the dominant source of variation is the cross-section. As there are very few alternative measures of $E P$, we consider only the Nickell et al. version in our baseline results, but in section 3.2 we consider an alternative measure as a robustness exercise. $T U$ is defined as the percentage of the workforce that belong to a trade union, and is also taken from Nickell 
et al. (2005). We include $T U$ because it is a relatively continuous measure of labor market characteristics compared to the discrete indices for coordination and employment protection. In the regression specification it may either capture the extent to which labor supply can resist wage moderation, or proxy an aspect of coordination not incorporated in our main measures. We remain agnostic on this issue.

In table 2 we present a correlation matrix for $S A C$ and the labor market variables. The three separate dimensions of the labor market structure (coordination, employment protection and unionization) are not highly correlated. This suggests that regressor multicollinearity will not be a major problem in our empirical work. The unconditional correlation between the sacrifice ratio and coordination is negative; those between the sacrifice ratio and employment protection and the sacrifice ratio and unionization are positive but very close to zero.

The vector $X$ comprises a set of controls emphasized in the literature. The first three are discussed by Ball (1994): INFLOSS, the percentage point change in inflation during the disinflation, $P E A K$, the percentage inflation rate at the start of the disinflation and $S P E E D$, the speed of disinflation defined as INFLOSS divided by the duration in years of a disinflation. ${ }^{6}$ Data for these variables (and also $S A C$ ) for the pre-1990 period were downloaded from the website of Jonathan Temple, who tabulated the data in Ball (1994). Data for the post-1990 period for these variables were taken from Bowdler (2009). The other covariates are OPEN, the average percentage share of imports in GDP during the years in which the disinflation occurred $^{7}, C B I$, Cukierman's (1992) index of the legal independence of central banks, the

\footnotetext{
${ }^{6} \mathrm{~A}$ referee pointed out the potential endogeneity of INFLOSS (and hence SPEED) given that it enters the sacrifice ratio denominator. In section 3 we check that such endogeneity does not induce or obscure our main results through reporting models with and without the INFLOSS and SPEED controls, and using the reciprocal of the length in years of a disinflation as an alternative definition of SPEED.

${ }^{7}$ Underlying data are from the IMF's International Financial Statistics database. For the German disinflation
} 
interaction of $O P E N$ and $C B I$ (see Daniels et al. 2005) and RIGHT, a binary variable equal to 1 if the government in office is from the political right for the duration of the disinflation and 0 otherwise (see Caporale and Caporale, 2008, whose classification of governments is from Alesina, Roubini and Cohen, 1997). ${ }^{8}$

\subsection{Sample and Estimation}

Our baseline sample comprises 76 disinflation episodes from 17 countries,${ }^{9} 61$ are from Ball (1994) and occur pre-1990 and 15 are from Bowdler (2009) and occur post-1990. We use 61/65 disinflations from the original Ball sample (corresponding to 17/19 of the countries considered by Ball) because (i) in line with recent studies such as Daniels et al. (2005) and Caporale and Caporale (2008), the observation for Luxembourg is excluded due to there being no corresponding observation for central bank independence $(C B I)$, and (ii) the three observations for Spain are omitted because the Kenworthy version of $C O I B$ is not calculated for Spain (Kenworthy justifies this decision on the grounds that labor market structures are difficult to assess in the period in which Spain was not a democracy). The 15 episodes taken from Bowdler (2009) of 1965-67 the data were not available and therefore the average openness statistic for 1970 is used (this is the closest year to 1967 for which data are available). The results reported in section 3 are robust to excluding this observation.

${ }^{8}$ Goncalves and Carvalho (2008) control for the presence of an inflation target and an index of the transparency of the central bank. Only 8/17 countries that adopted inflation targeting in the Goncalves-Carvalho sample are represented in our sample, and of those 8 only a handful undertook a disinflation since the transition to inflation targeting. Therefore a control for inflation targeting does not affect our main results, even though it represents an important influence in other samples. Similarly, the transparency index is insignificant when added to the models that we estimate (as it was in the Goncalves and Carvalho study) and therefore we do not include it in our core analysis.

${ }^{9}$ These are Australia, Austria, Belgium, Canada, Denmark, Finland, France, Germany, Ireland, Italy, Japan, Netherlands, New Zealand, Sweden, Switzerland, UK, USA. 
are Australia 1989 - 93, Belgium 1990 - 95, Canada 1990 - 94, Denmark 1988 - 93, Finland 1989 - 96, France 1990 - 94, Ireland 1989 - 93, Italy 1990 - 94, Japan 1990 - 95, Netherlands 1991 - 96, Sweden 1990 - 98, Switzerland 1991 - 98, UK 1990 - 93 and US $1990-94$.

We estimate several versions of equation (1) by OLS and compute standard errors after clustering at the country level in order to allow for heteroscedasticity and residual serial correlation of unknown form.

\section{Results}

In table 3 we present our baseline regression estimates. The first and second columns confirm the main findings from recent studies of the sacrifice ratio using the sample that we have constructed. As in Daniels et al. (2005) openness to trade increases the sacrifice ratio after controlling for its interaction with $C B I$, although unlike in the Daniels et al. results the interaction $O P E N * C B I$ is sufficiently negative that the marginal effect from openness (calculated by setting $C B I$ to its sample mean) is negative. This is consistent with the finding from Bowdler (2009) that sacrifice ratios from the 1990s are more highly negatively correlated with trade openness. ${ }^{10}$ In terms of the measure of political stance, we find that, per unit, the output cost of disinflation is 0.47 percentage points lower when overseen by right wing governments. This estimate is approximately two thirds that obtained by Caporale and Caporale (2008) using a comparable specification (table 5, column 3 in their paper), and is significant at the $15 \%$ level whereas the Caporale and Caporale estimate was significant at the $10 \%$ level. The evidence for smaller

\footnotetext{
${ }^{10}$ Daniels et al. control for the length of a disinflation rather than its speed, and, in their most general specification, condition on the measure of wage duration employed by Ball (1994). If the column 1, table 3 specification is changed so that $S P E E D$ is omitted and the two Daniels et al. controls are added, our results on trade openness and central bank independence are unchanged.
} 
sacrifice ratios under right wing governments is slightly weaker when the sample is expanded using Bowdler (2009) rather than Andersen and Wascher (1999).

In columns $3-5$ we study the effects of labor market structures on the sacrifice ratio, first in isolation, then adding other controls. Using the column 3 estimates, an increase in the degree of labor market coordination is associated with smaller sacrifice ratios, consistent with the notion that coordination between labor unions facilitates the wage adjustment required for disinflation. The estimate is significant at the $1 \%$ level in all specifications. The EP index of employment protection laws increases disinflation costs, although the effect is significant only at the $10 \%$ level in the column 4 specification and is less significant in other cases. ${ }^{11}$ Any positive correlation between employment protection indices and the sacrifice ratio could arise if employment protection confers on workers and unions the power to resist wage moderation, delay disinflation and raise disinflation costs. For example, in the case of the United Kingdom, disinflation was implemented more rapidly and at lower cost in the 1980s than in the 1970s, following the rolling back of employment protection legislation under the Thatcher government. On the other hand, the $T U$ variable is robustly insignificant, indicating no evidence that this measure of the potential importance of unions in wage agreements influences disinflation costs. ${ }^{12}$

The standardized coefficients for labor market structures, obtained by multiplying the regression coefficients by the ratio of the standard deviation of a labor market variable to the

\footnotetext{
${ }^{11}$ In footnote 6 we noted the potential endogeneity of INFLOSS and SPEED. If those two variables are omitted from the column 4 specification, the t-ratio for $C O I B$ is 2.38 and that for $E P$ is 1.94 . Adding the recipriocal of the length in years of a disinflation to that regression gives t-ratio of COIB of 3.06 and a t-ratio for $E P$ of 2.05 (the inverse length variable has a $t$-ratio of 3.32 ).

${ }^{12}$ If the $T U$ term is deleted from the parsimonious specification in column 3, COIB is significant at the $1 \%$ level and $E P$ at the $20 \%$ level. If the $T U$ term is deleted from the specification in column $4, C O I B$ is significant at the $1 \%$ level and EP is significant at the $7 \%$ level.
} 
standard deviation of the sacrifice ratio, are (using the column 4 estimates) 0.29 for COIB and 0.23 for $E P$. These effects are far from one-for-one and illustrate what is revealed in the column $2 R^{2}$ statistic - labor market structures account for only a small proportion of the variation in sacrifice ratios. However, this is not to say that labor market structures do not exert an economically meaningful effect on disinflation costs. For example, according to our column 4 estimates, an increase in $C O I B$ from the level recorded in the United States and Canada to the level recorded in Japan, reduces the cost of a 5 percentage point disinflation by $6.4 \%$ of GDP. Similarly, a loosening of employment protection from the levels seen in Italy and Sweden to those in the United States could save $6.2 \%$ of GDP during a $5 \%$ disinflation. These calculations should, of course, be interpreted with caution, for example it is not clear that a country could overhaul employment protection laws whilst leaving all other features of its labor markets unchanged, but they do suggest that differences in labor market structures exert a meaningful effect on disinflation experiences.

In column 5 of table 3 we control for the measure of wage flexibility (WAGE FLEX) due to Bruno and Sachs (1985) and discussed in section 1 in the context of Ball's analysis of the sacrifice ratio (data restrictions reduce the sample to 72 in this case). The magnitude and significance of the $C O I B$ effect are unchanged, while the magnitude and significance of the $E P$ effect both fall relative to column 4 . In section 1 we argued that labor market characteristics influence sacrifice ratios via wage dynamics, and it is therefore interesting to note that WAGE FLEX is insignificant and does little to affect the role of labor market variables. There are three points to bear in mind in relation to this issue. Firstly, some of the effects of wage flexibility may operate through other controls. For example, in flexible economies policy-makers may have an incentive to launch rapid disinflations because the associated output costs are small, in which case the variable $S P E E D$ would capture some of the effect of wage flexibility. A regression 
of $S A C$ on $W A G E F L E X$ yields a slope coefficient that is significant at the $5 \%$ level, giving some credence to this view, though clearly such a simple model is open to the standard omitted variables critique. Secondly, it is important to note that $W A G E F L E X$ is a de jure measure of wage flexibility, in that it indicates the likely degree of flexibility given the extent of wage indexation, the duration of wage contracts and the synchronization of wage negotiations. It is not the actual or de facto level of wage flexibility, which matters for disinflation dynamics in practice. It is therefore possible that the labor market variables contain information regarding nominal flexibility over and above that in $W A G E F L E X$, for example COIB may proxy the amount of wage adjustment unions actually agree to during negotiations. Thirdly, WAGE $F L E X$ varies only in the cross-section and has not been updated since its formulation in the 1980s, whereas the measures of labor market structures due to Kenworthy and Nickell et al. exhibit time-variation and are updated through 2000. Overall, we argue that the insignificance of $W A G E F L E X$ is not at odds with the evidence that labor market features are important determinants of sacrifice ratios.

\subsection{Testing for Non-linearity}

As discussed in section 2, the degree of coordination in wage-setting is related to the centralization of wage-setting, which is essentially the inverse of the number of trade unions in the market. The effects of centralized wage-setting on unemployment and inflation outcomes have been investigated in a number of papers, for example Calmfors and Driffill (1988) and Daniels, Nourzad and VanHoose (2006). An important theme in these papers is that increases in wage centralization from a low base may increase inflation and unemployment, because the growth of labor unions creates monopoly power in labor markets and raises real wages relative to the competitive level. The incentive for centralized unions to moderate wage claims in order to 
improve macroeconomic outcomes starts to dominate only at higher levels of centralization, yielding the famous inverse U-shape effect from centralization. Although we stress the distinction between centralization measures and our coordination indices (see section 2), we investigate non-linearities in the effects of coordination on sacrifice ratios given their importance in the literature on centralization.

In order to do this we generated five dummy variables, one for each of the five tiers from the Kenworthy $C O I B$ index. We then replaced $C O I B$ with the dummy variables corresponding to categories 2 through 5, the omitted dummy being subsumed in the regression intercept (if this dummy were to be added it would be collinear with the intercept and the other dummy variables). The included dummy variables measure the incremental effect of $C O I B$ in each tier relative to the lowest tier $(C O I B=1)$, which is the excluded category. Under the inverse U-shape hypothesis the dummy variable coefficients should be positive for intermediate tiers (indicating a smaller negative effect of $C O I B$ on the sacrifice ratio at intermediate levels of coordination) and negative, or at least smaller, for the extreme tiers (indicating large reductions in the sacrifice ratio at very high or very low levels of coordination). ${ }^{13}$ In table 4 we report the sequence of dummy variable coefficients and absolute t-ratios obtained after clustering at the country level, for three sets of regression controls: (A) PEAK, INFLOSS, SPEED, OPEN, $C B I$ and $O P E N * C B I$; (B) the model (A) controls plus RIGHT; (C) the model (B) controls plus $E P$ and $U D N E T$.

The results provide only weak evidence for the inverse U-shape. The middle three tiers from

\footnotetext{
${ }^{13}$ The use of the composite $C O I B$ variable up to this point is equivalent to imposing the restriction that the dummy variable coefficients vary linearly. The negative $C O I B$ effect, for instance, implies a linearly decreasing sequence of dummy variable coefficients. The most important difference between that case and the inverse U-shape is that the latter implies a non-monotonic relationship between the sacrifice ratio and $C O I B$.
} 
$C O I B$ consistently trace out the inverse $\mathrm{U}$-shape, but only the tier 4 coefficients are statistically significant at conventional levels of confidence. Furthermore, sacrifice ratios in tier 1 are 0.23 , 0.004 or 0.61 percentage points larger than in tier 2 (depending on the regression specification), and sacrifice ratios in tier 5 are $0.50,0.42$ or 0.17 percentage points larger than in tier 4 . As such, the coefficients suggest multiple peaks in the effects of $C O I B$, consistent with a $\mathrm{W}$-shape, though as noted above the majority of these coefficient estimates are not significant. In essence, our results provide evidence that high levels of coordination reduce sacrifice ratios relative to low levels of coordination, but no evidence that low levels of coordination are associated with smaller sacrifice ratios than are intermediate levels of coordination.

\subsection{Robustness}

In this sub-section we first consider the robustness of our baseline results to alternative estimation strategies, variable measurements and sample definitions. We then investigate the relationship between labor market structures and different concepts of the sacrifice ratio. These are derived from alternative assumptions regarding the behavior of trend output during disinflations and therefore yield different measures of the output loss from disinflation. Given the importance of trend output assumptions in quantifying the output cost of disinflation, this represents an important test of the robustness of our baseline results.

In the first column of table 5 we extend the table 3 , column 4 regression to control for a full set of country fixed effects and decade dummies for disinflations occurring in the 1970s, 1980s and 1990s (when disinflations span decades they are allocated to the decade in which most of the disinflation occurred). The effect from $C O I B$ is significant at the $5 \%$ level. This indicates that more coordinated wage-setting is associated with smaller disinflation costs not only across countries, but also within countries through time. On the other hand, the effect of stricter 
employment protection, which was marginally significant in the baseline results, is essentially zero when estimated purely from time series variation in the data. This reflects the lack of time variation in $E P$. We address this issue by turning to an alternative index of employment protection due to Allard (2003). This index increases with employment protection, on a scale from 0 to 5 . Importantly, it exhibits more time variation than the standard employment protection index used in our baseline regressions (Allard and Lindert, 2006). In column 2 we use the new employment protection measure and a full set of fixed effects and time dummies. The $E P$ effect is significant at the $5 \%$ level, providing stronger evidence that within country increases in employment protection raise disinflation costs.

Extending the use of alternative measures of labor market structures, in column 3 we replicate the column 2 regression but using a new version of $C O I B$. This is a de facto index of coordination amongst wage-setters from Nickell, Nunziata and Ochel (2005). The index builds on the OECD measure of the centralization of wage bargaining, to reflect the extent to which labor market actors take into account the macroeconomic consequences of their decisions. See Nickell et al. for further discussion. The index increases in the degree of coordination, from a minimum of 1 to a maximum of 3 , and varies across both dimensions of the panel. We consider this index because it is not mentioned as an input to the Kenworthy index, and is an explicitly de facto index that may capture information not contained in the de jure measure, which concentrates on the expected degree of coordination given observed characteristics. The COIB coefficient in column 3 is significant at the $5 \%$ level (the coefficient rises substantially relative to previous estimates due to the smaller range over which the Nickell et al. index is defined). The EP measure from Allard remains significant at the $5 \%$ level in column 3. Beyond the labor market variables, a number of covariates are less significant in the fixed effects specification, and $C B I$ drops out of the regression because it is time invariant. 
Our next robustness exercise involves trimming the sample through excluding observations for which Cook's distance statistic (computed from the table 3, column 4 specification) exceeds the ratio $\frac{4}{\text { degrees of freedom }}$, the threshold recommended in Belsey, Kuh and Welsch (1980). Using this criterion just one observation is excluded: Finland $1989-96$. The $C O I B$ and $E P$ effects decrease in magnitude relative to table 3 column 4, but the $C O I B$ effect is significant at the $5 \%$ level and the EP effect is significant at the $10 \%$ level.

In the final column of table 5 we replace the variable PEAK with INF HISTORY, defined, following Hofstetter (2008), as the average annual inflation rate during the ten years immediately prior to the year in which disinflation commenced. The motivation for this exercise is twofold. Firstly, the variable INF HISTORY is less likely endogenous to the sacrifice ratio via the sacrifice ratio denominator than is $P E A K$ (recall that $P E A K$ is measured in the year in which disinflation commences, unlike INF HISTORY which is from the decade prior to that year). Secondly, Smith and Senda (2008) show that measures of inflation history play a more important role in explaining the sacrifice ratio than does the inflation peak prior to disinflation, suggesting it may be a more important control in evaluating the robustness of the relationship between labor market structures and the sacrifice ratio. ${ }^{14}$ The results in table 5 , column 5 confirm the Senda and Smith finding, in that INF HISTORY is significant at the $5 \%$ level, whereas PEAK was insignificant in all previous specifications. Further, the effects of $C O I B$ and $E P$ increase in magnitude and statistical significance relative to the table 3, column 4 results.

The final issue that we address relates to a recent contribution by Goncalves and Carvalho (2009), who contend that the role of variables measuring institutions (in their case, the presence of an inflation target for policy-makers) may be subject to bias via a selection effect. Specifically,

\footnotetext{
${ }^{14}$ Senda and Smith define inflation history using geometrically declining weights, but note that their results are unaffected when using the unweighted average.
} 
countries in which the sacrifice ratio is inherently low, and which can therefore offset positive inflation shocks at little cost, may institute inflation targeting regimes more readily given that hitting the target is less costly. A correction for selection bias based on Heckman's procedure is then implemented. We have not pursued a similar exercise in respect of labor market institutions, and leave detailed analysis of the determinants of labor market institutions for future research. However, some relevant insights can be gleaned from our fixed effects regressions in columns 1 and 2 in table 5 . The possibility that cross-country variation in labor market structures is selected in response to international differences in the expected sacrifice ratio, and that this selection effect accounts for our results, can be ruled out in these instances. The reason is that the regression slopes are estimated purely from temporal variation in the data. The evidence for the robustness of our results after controlling for fixed effects, suggests that our findings are not driven by a cross-sectional selection effect. There remains the possibility that countries re-configure labor market structures through time in response to changes in the sacrifice ratio. This cannot be ruled out using our current research design - including a set of time dummies does not control for selection effects along the time dimension. Evidence from the historical record suggests that major changes in the structure of labor market institutions are endogenous to economic conditions, e.g. in the United Kingdom following the election of Margaret Thatcher, but whether the magnitude of the sacrifice ratio is one of those conditions is an open question.

\subsubsection{Alternative Measures of the Sacrifice Ratio}

A valid assessment of the importance of labor market structures for disinflation costs depends critically on accurate measurement of the sacrifice ratio. In recent contributions, Zhang (2005) and Hofstetter (2008) have proposed measures of the sacrifice ratio calculated under alternative assumptions concerning the evolution of trend output, and which therefore yield different mea- 
sures of the output losses associated with inflation reduction. Recall that the vital assumptions made in Ball (1994) concerning trend output are (i) trend output obtains in the year of an inflation peak; (ii) trend output obtains one year after the end of a disinflation. Under these assumptions, and given linear adjustment of trend output during a disinflation, calculation of the output sacrifice is straightforward. Zhang focuses on the second of the Ball postulates. Specifically, following large policy contractions, output may not equilibrate until more than one year after inflation ceases to fall. In such cases, the Ball method will understate the sacrifice ratio associated with disinflation. Motivated by this concern, Zhang calculates alternative sacrifice ratios assuming trend output during disinflation grows at the same rate as the Hodrick Prescott trend for output calculated at the start of the disinflation. If output equilibrates more slowly than assumed by Ball, output losses relative to trend will be larger and more persistent, leading to larger sacrifice ratios.

Hofstetter (2008) takes this approach to evaluating output losses relative to trend one step further through probing the Ball assumption that output is equal to trend at the start of a disinflation. In particular, Hofstetter imposes the alternative assumption that output is equal to trend the year before the start of a disinflation and then grows at the same rate as the Hodrick-Prescott trend for output computed for that year. As discussed by Hofstetter (2008), this method will identify larger sacrifice ratios than both the Ball and Zhang methods if actual output is below trend at the time disinflation commences (see figure 6 in Hofstetter (2008) for a comparison of the three methods). Output may fall below trend prior to an inflation peak if aggregate demand contractions are launched while inflation is still rising, and these demand contractions then affect output with a shorter lag than inflation (this timing is consistent with the textbook assumption that quantities respond to demand shocks more quickly than prices). In such instances, output sacrifices will be experienced even before disinflation commences. It 
is instances of this sort that Hofstetter's procedure can handle, but Ball's method cannot.

In order to assess the importance of measurement of the sacrifice ratio for the relationship between labor market structures and disinflation costs, we use data from Senda and Smith (2008) who calculate sacrifice ratios using the methods proposed by Ball, Zhang and Hofstetter for 77 disinflations occurring between 1960 and 1998. The data vintage used by Senda and Smith is more recent than that employed by Ball (1994) and consequently the datings of disinflations, as well as the magnitudes of sacrifice ratios, differ slightly from those used in our baseline estimations. We use Senda and Smith's sacrifice ratios calculated via Ball's method as a test of the robustness of our baseline results to the use of a more recent data vintage, in addition to using Senda and Smith's sacrifice ratios calculated using the Zhang and Hofstetter methods to determine the implications of alternative assumptions regarding trend output during disinflations.

We constructed a database comprising the sacrifice ratios from Senda and Smith and added measures of each of the covariates described in section 2 (the variables PEAK and INFLOSS were taken from Senda and Smith). In the new sample of 77 sacrifice ratios the average sacrifice ratio calculated using Ball's, Zhang's and Hofstetter's methods are 1.17\%, 2.65\% and 3.22\% respectively. Consistent with the arguments presented in Zhang and Hofstetter, sacrifice ratios are larger when calculated using alternative assumptions on the evolution of trend output. The sample correlation between the Ball and Zhang measures is 59\%, while that between the Ball and Hofstetter measures is $64 \%$. The new data were then used to estimate three sets of regressions for each of the three versions of the dependent variable. The three sets of regression controls were (A) COIB, EP and UDNET; (B) the controls in (A) plus INFLOSS, INF HISTORY and LENGTH (the length of the disinflation in years); (C) the controls in (B) plus OPEN, $C B I, O P E N * C B I$ and RIGHT. 
The results for $C O I B$ and $E P$ are presented in table 6 . In the parsimonious regression specification in row A the negative effect of labor market coordination is weak using each of the three measures of the sacrifice ratio. Conditioning on the controls in Senda and Smith (2008), in row $\mathrm{B}$, increases the strength of these effects such that they are significant at the $5 \%, 11 \%$ and 26\% levels for the Ball, Zhang and Hofstetter measures. As in Senda and Smith's results, INF HISTORY and LENGTH are particularly important controls. On the other hand, the significance of the results is weaker after controlling for the row $\mathrm{C}$ covariates. An inspection of the partial regression plots for $C O I B$ (not reported here) indicates that the low levels of significance are mainly due to the observation for New Zealand, $1994-98$. Interestingly, all three measures of the sacrifice ratio are negative for this episode, which is at odds with the usual presumption that disinflation requires an output sacrifice. In the right-hand panel of table 6 we replicate the $C O I B$ estimates for a sample of 76 disinflations that excludes the $1994-98$ episode for New Zealand. The results are somewhat stronger in this case. In row B, the negative effect from $C O I B$ is significant at the $10 \%$ level for each of the three sacrifice ratio concepts (and significant at the $1 \%$ level using the Ball measure), while in row $\mathrm{C}$, which includes the broadest range of controls, the $C O I B$ effects are always significant at the $15 \%$ level (and significant at the $1 \%$ level using the Ball measure). Overall, whilst the relationship between labor market coordination and the sacrifice ratio is less strong using sacrifice ratios calculated using different assumptions concerning trend output, it remains negative, and is borderline significant in some samples and regression specifications. In contrast, the EP effect, which was more marginal in the baseline results, is insignificant using the new sacrifice ratio concepts, and changes signs in some instances. Accordingly, we emphasize our results for $C O I B$ ahead of those for $E P$. 


\section{Summary}

In this paper we have examined the relationship between labor market structures and international differences in the sacrifice ratio, a measure of the output cost of disinflation. The main finding is that coordination between wage-setters in the labor market reduces the sacrifice ratio, although the statistical significance of this finding is sensitive to the use of alternative procedures for measuring the sacrifice ratio. A potential explanation for this finding is that coordinated wage-setting facilitates the moderation of nominal wage growth required for disinflation. An index of employment protection increases the sacrifice ratio but the relationship is not significant at conventional levels. Our results indicated that these effects operate even after controlling for a measure of wage flexibility previously studied in the literature, suggesting that the indices of labor market structures we study contain information beyond that in standard measures of wage flexibility. Unlike in the related literature on the centralization of wage-setting, we found only weak evidence for an inverse U-shape effect from coordination. The robustness of the core results was investigated in some detail. The basic effects of labor market structures remained intact after holding constant a wide range of variables that have been studied in the literature, and also after controlling for outliers in the data. The effect of coordination was robust when measured using a different method, but was less strong in a sample of sacrifice ratios measured using different assumptions concerning trend output during disinflations.

\section{References}

Alesina, Alberto, Nouriel Roubini and Gerald Cohen, (1997). Political Cycles in the Macroeconomy. The MIT Press, Cambridge MA.

Allard, Gayle (2003). Jobs and Labor Market Institutions in the OECD. Doctoral dissertation, University of California, Davis. 
Allard, Gayle and Peter Lindert (2006). "Euro-productivity and Euro-jobs since the 1960s: Which institutions mattered?" Instituto de Empresa working paper number 22.

Andersen, Palle and William Wascher, (1999). "Sacrifice Ratios and the Conduct of Monetary Policy in Conditions of Low Inflation." Bank for International Settlements working paper 82.

Ball, Laurence (1987). "Externalities from Contract Length." American Economic Review, $77,615-29$.

Ball, Laurence and David Romer (1991). "Sticky Prices as Coordination Failure." American Economic Review, 81, 539-52.

Ball, Laurence (1994). "What determines the sacrifice ratio?" In Mankiw, N. G. ed. Monetary Policy, 155-182. University of Chicago Press, Chicago.

Belsey, David, Edwin Kuh and Roy Welsch (1980). Regression Diagnostics: Identifying Influential Data and Sources of Collinearity. John Wiley. New York.

Boschen, John and Charles Weise (2001). "The Ex Ante Credibility of Disinflation Policy and the Cost of Reducing Inflation." Journal of Macroeconomics, 323-47.

Bowdler, Christopher (2009). "Openness, Exchange Rate Regimes and the Phillips Curve." Journal of International Money and Finance, 148-60.

Bruno, Michael and Jeffrey Sachs (1985). Economics of Worldwide Stagflation. Harvard University Press, Cambridge, MA.

Calmfors, Lars and John Driffill (1988). "Bargaining structure, corporatism, and macroeconomic performance." Economic Policy, 14-61.

Calmfors, Lars (2004). "Wages and Wage Bargaining Institutions in the EMU - A Survey of the Issues." Seminar Paper no. 690, Institute for International Economic Studies, Stockholm. Caporale, Barbara and Tony Caporale (2008). "Political Regimes and the Cost of Disinfla- 
tion." Journal of Money, Credit and Banking, 1541-54.

Chortareas, Georgios, David Stasavage and Gabriel Sterne (2003). "Does Monetary Policy Transparency Reduce Disinflation Costs?" Manchester School, 71, 521-40.

Cukierman, Alex (1992). Central bank strategy, credibility and independence: theory and evidence. The MIT Press, Cambridge MA.

Daniels, Joseph, Farrokh Nourzad and David VanHoose (2005). "Openness, central bank independence and the sacrifice ratio." Journal of Money, Credit and Banking, 37, 371-79.

Daniels, Joseph, Farrokh Nourzad and David VanHoose (2006). "Openness, centralized wage bargaining and inflation." European Journal of Political Economy, 969-88.

Flanagan, Robert (1999). "Macroeconomic Performance and Collective Bargaining: An International Perspective." Journal of Economic Literature, 1150-75.

Goncalves, Carlos Eduardo and Andre Carvalho (2009). "Inflation Targeting Matters: Evidence from OECD Economies' Sacrifice Ratios." Journal of Money, Credit and Banking, 233-43. Hofstetter, Marc (2008). "Disinflations in Latin America and the Carribean: A Free Lunch?" Journal of Macroeconomics, 30, 327-45.

Jordan, Thomas (1997). "Disinflation Costs, Accelerating Inflation Gains, and Central Bank Independence." Weltwirtschaftliches Archiv, 1-21.

Kenworthy, Lane (2001). "Wage-Setting Coordination Scores." Dataset available at www.emory.edu/SOC/lkenworthy/.

Kenworthy (2003). "Quantitative Indicators of Corporatism." International Journal of Sociology, 10-44.

Nelson, E., 2005. "The Great Inflation of the Seventies: What Really Happened?" Advances in Macroeconomics, volume 5, article 3.

Nickell, Stephen, Luca Nunziata and Wolfgang Ochel (2005). "Unemployment in the OECD 
since the 1960s. What do we know?" Economic Journal 115, 1-27.

Nunziata, Luca (2005). "Institutions and Wage Determination: A Multi-Country Approach." Oxford Bulletin of Economics and Statistics 67, 435-466.

Olivei, Giovanni and Silvana Tenreyro (2007). "The Timing of Monetary Policy Shocks." American Economic Review, 97, 636-663.

Razin, Assaf and Prakash Loungani (2005). "Globalization and Inflation-Output Tradeoffs." NBER working paper 11641.

Romer, David (1993). "Openness and Inflation: Theory and Evidence." Quarterly Journal of Economics, 108, 869-903.

Senda, Takashi and Julie Smith (2008). "Inflation History and the Sacrifice Ratio: EpisodeSpecific Evidence" Contemporary Economic Policy, 26, 409-19.

Soskice, David (1990). "Wage Determination: The Changing Role of Institutions in Advanced Industrialized Countries." Oxford Review of Economic Policy, 36-61.

Taylor, John (1983). "Union Wage Settlements During a Disinflation." American Economic Review, 73, 981-93.

Temple, Jonathan (2002). "Openness, Inflation and the Phillips Curve: A Puzzle." Journal of Money, Credit and Banking, 34, 450-468.

Thomas, Alun (2002). "The Costs and Benefits of Various Wage Bargaining Structures: An Empirical Exploration." International Monetary Fund working paper 02/71.

Zhang, Lawrence (2005). "Sacrifice Ratios with Long-lived Effects." International Finance, $231-62$. 


\begin{tabular}{lcccc}
\hline \multicolumn{4}{c}{ Table 1: Descriptive Statistics (Disinflation Episodes Spanning 1961-98) } \\
\hline \hline SAC & Mean & Std. Dev. & Min & Max \\
COIB & 1.06 & 1.59 & -1.85 & 10.53 \\
EP & 3.43 & 1.45 & 1 & 5 \\
TU & 0.95 & 0.56 & 0 & 2 \\
OPEN & 0.44 & 0.17 & 0.1 & 0.82 \\
CBI & 27.85 & 13.41 & 5.3 & 68 \\
RIGHT & 0.37 & 0.15 & 0.16 & 0.68 \\
PEAK & 0.42 & 0.5 & 0 & 1 \\
SPEED & 7.73 & 3.95 & 1.27 & 17.6 \\
INFLOSS & 1.58 & 0.84 & 0.32 & 3.92 \\
\hline
\end{tabular}

The table reports summary statistics for the variables used in the baseline regressions, see the text for variable definitions and discussion. All ststistics are calculated for the core sample of 76 observations used in the table 3 regressions.

Table 2: Correlations for Selected Series (Disinflations Spanning 1961-98)

\begin{tabular}{lcccc}
\hline \hline & SAC & COIB & EP & TU \\
\cline { 2 - 5 } SAC & 1 & & & \\
COIB & -0.25 & 1 & & \\
EP & 0.001 & 0.48 & 1 & 1 \\
TU & 0.022 & 0.33 & 0.18 & 1 \\
\hline
\end{tabular}

The correlation coefficients are calculated for the core sample of 76 observations used in the table 3 regressions. 


\begin{tabular}{|c|c|c|c|c|c|}
\hline & 1 & 2 & 3 & 4 & 5 \\
\hline$\overline{\mathrm{COIB}}$ & & & $-0.43(2.79)^{* *}$ & $-0.32(2.70)^{* *}$ & $-0.32(2.78)^{* *}$ \\
\hline $\mathrm{EP}$ & & & $0.42(1.21)$ & $0.65(1.78)$ & $0.47(1.47)$ \\
\hline TU & & & $1.17(0.63)$ & $1.59(0.86)$ & $1.98(0.88)$ \\
\hline OPEN & $0.04(1.76)$ & $0.04(1.86)$ & & $0.03(2.28)^{*}$ & $0.02(1.25)$ \\
\hline CBI & $6.62(3.36)^{* *}$ & $6.99(3.46)^{* *}$ & & $6.61(4.19)^{* *}$ & $4.86(2.43)^{*}$ \\
\hline $\mathrm{OPEN}^{*} \mathrm{CBI}$ & $-0.18(2.98)^{* *}$ & $-0.18(3.04)^{* *}$ & & $-0.13(3.17)^{* *}$ & $-0.09(1.78)$ \\
\hline PEAK & $-0.01(0.10)^{* *}$ & $-0.01(0.19)$ & & $-0.05(0.54)$ & $-0.05(0.56)$ \\
\hline SPEED & $-0.82(4.10)$ & $-0.72(3.50)^{* *}$ & & $-0.56(3.69)^{* *}$ & $-0.64(4.35)^{* *}$ \\
\hline INFLOSS & $0.17(1.63)$ & $0.15(1.51)$ & & $0.15(0.44)$ & $0.15(1.68)$ \\
\hline RIGHT & & $-0.47(1.55)$ & & $-0.46(1.53)$ & $-0.35(1.23)$ \\
\hline WAGE FLEX & & & & & $-0.07(0.52)$ \\
\hline $\mathrm{R}^{2}$ & 0.24 & 0.26 & 0.11 & 0.32 & 0.33 \\
\hline Sample size & 76 & 76 & 76 & 76 & 72 \\
\hline
\end{tabular}

The dependent variable is the sacrifice ratio. See the text for details concerning the measurement of the sacrifice ratio and the regressors. All regressions include an intercept. The figures in parentheses are absolute t-ratios based on standard errors calculated after clustering at the country level. ** and * denote significance at the $1 \%$ and $5 \%$ levels respectively. 


\begin{tabular}{cccc}
\hline Table 4: Non-linear Effects of Coordination & (Disinflations Spanning 1961-98) \\
\hline \hline COIB SCORE & A & B & C \\
\hline 2 & -0.23 & -0.004 & -0.61 \\
& $(0.47)$ & $(0.01)$ & $(1.41)$ \\
3 & 1.09 & 1.21 & 0.7 \\
& $(1.24)$ & $(1.35)$ & $(0.91)$ \\
4 & -0.75 & -0.59 & -1.22 \\
& $(3.63)^{* *}$ & $(2.64)^{*}$ & $(4.35)^{* *}$ \\
5 & -0.25 & -0.17 & -1.05 \\
& $(0.94)$ & $(0.62)$ & $(1.88)$ \\
\hline
\end{tabular}

Estimates of the change in the sacrifice ratio from each COIB category relative to category one

of COIB (the excluded category). The figures in parentheses are absolute t-ratios based on standard errors calculated after clustering at the country level. ** and * denote significance at the $1 \%$ and $5 \%$ levels respectively. Column A results are from a regression that includes PEAK, INFLOSS, SPEED, OPEN, CBI and OPEN*CBI. Column B results are from a regression that contains the colum A variables plus RIGHT. Column $\mathrm{C}$ results are from a regression that contains the column B variables plus EP and UDNET. 
Table 5: Robustness Tests for the Core Model (Disinflations Spanning 1961-98)

\begin{tabular}{|c|c|c|c|c|c|}
\hline & 1 & 2 & 3 & 4 & 5 \\
\hline COIB & $-0.61(2.66)^{*}$ & $-0.58(2.55)^{*}$ & $-2.49(2.37)^{*}$ & $-0.23(2.11)^{*}$ & $-0.40(3.46)^{* *}$ \\
\hline $\mathrm{EP}$ & $0.01(0.01)$ & $0.79(2.00)^{*}$ & $0.79(2.16)^{*}$ & $0.57(1.80)$ & $0.74(2.10)^{*}$ \\
\hline TU & $5.24(0.75)$ & $3.04(0.45)$ & $4.54(0.61)$ & $-0.24(0.24)$ & $2.16(1.19)$ \\
\hline OPEN & $-0.06(0.59)$ & $-0.07(0.67)$ & $-0.08(0.81)$ & $0.04(3.10)^{* *}$ & $0.02(1.02)$ \\
\hline CBI & & & & $7.32(5.65)^{* *}$ & $5.20(2.98)^{* *}$ \\
\hline $\mathrm{OPEN}^{*} \mathrm{CBI}$ & $0.22(0.63)$ & $0.11(0.33)$ & $0.02(0.08)^{* *}$ & $-0.15(3.55)^{* *}$ & $-0.09(1.76)$ \\
\hline PEAK & $0.06(0.42)$ & $0.07(0.53)$ & $-0.08(0.86)$ & $0.02(0.60)$ & \\
\hline SPEED & $-0.34(0.84)$ & $-0.38(1.14)$ & $-0.43(1.18)^{* *}$ & $-0.42(2.36)^{*}$ & $-0.59(2.96)^{* *}$ \\
\hline INFLOSS & $0.06(0.37)$ & $0.06(0.50)$ & $0.09(0.58)$ & $0.06(0.93)$ & $0.15(3.57)^{* *}$ \\
\hline RIGHT & $-0.50(1.04)$ & $-0.50(1.10)$ & $-0.56(1.30)$ & $-0.42(1.34)$ & $-0.56(1.88)$ \\
\hline INF HISTORY & & & & & $-0.14(2.10)^{*}$ \\
\hline$\overline{\text { ROBUSTNESS }}$ & FIXED EFFECTS & ALLARD EP, & ALLARD EP, NICKELL & EXCLUDE & INF HISTORY, \\
\hline TEST & \& TIME DUMMIES & FIXED EFFECTS & COIB, FIXED EFFECTS & OUTLIERS & NO PEAK \\
\hline & & \& TIME DUMMIES & \& TIME DUMMIES & & \\
\hline $\mathrm{R}^{2}$ & 0.56 & 0.58 & 0.58 & 0.45 & 0.35 \\
\hline Sample size & 76 & 76 & 76 & 75 & 76 \\
\hline
\end{tabular}

The dependent variable is the sacrifice ratio. See the text for details concerning the measurement of the sacrifice ratio and the regressors. All regressions include an intercept. The figures in parentheses are absolute t-ratios based on standard errors calculated after clustering at the country level. ** and ${ }^{*}$ denote significance at the $1 \%$ and $5 \%$ levels respectively. 
Table 6: Estimates from Alternative Sacrifice Ratio Measures (1960-98)

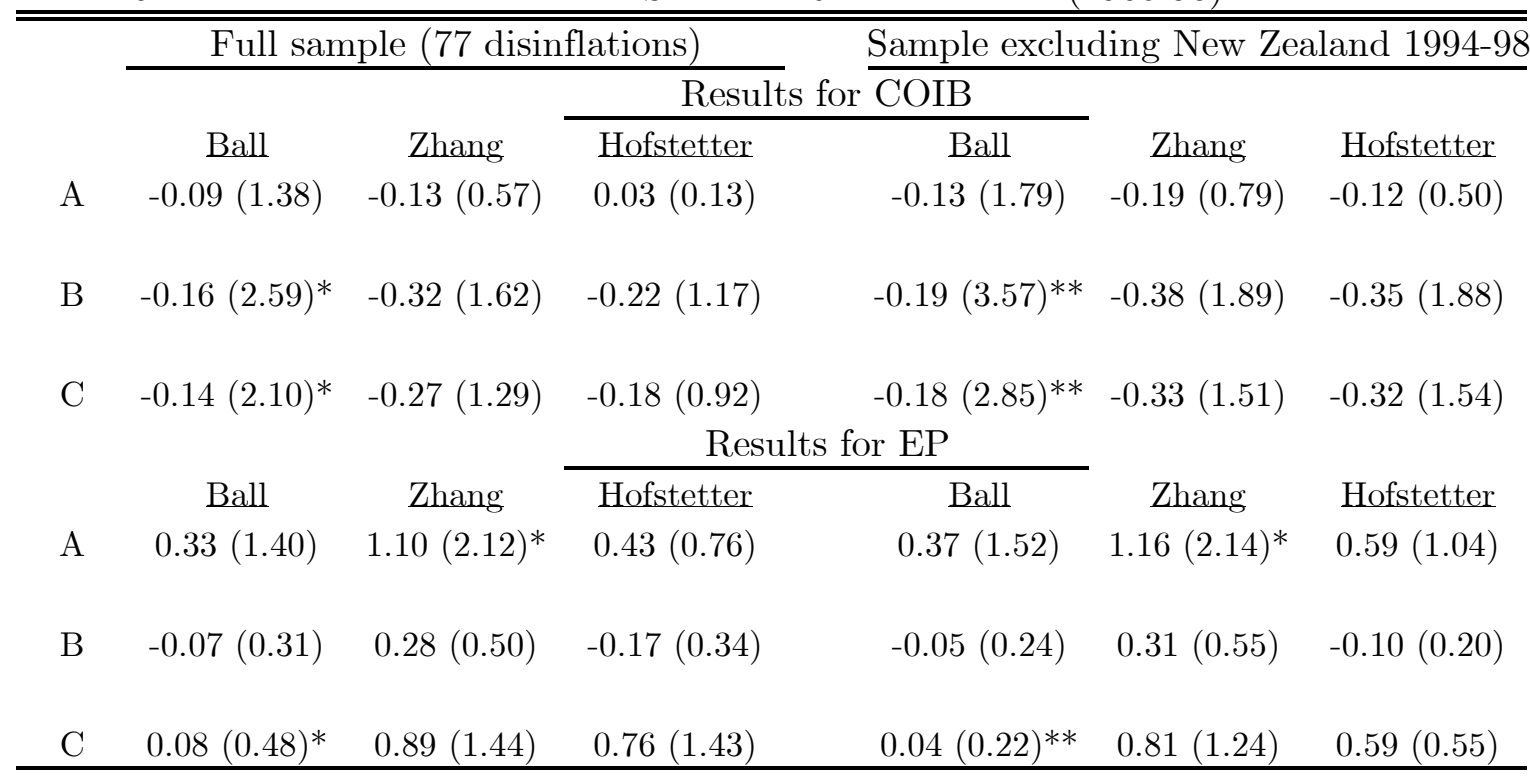

Estimates of the COIB and EP effects for Ball, Zhang and Hofstetter sacrifice ratios calculated by Senda and Smith (2008). The figures in parentheses are absolute t-ratios based on standard errors calculated after clustering at the country level. ** and * denote significance at the $1 \%$ and $5 \%$ levels respectively. Row A results are from regressions that control for COIB, EP and UDNET. Row B results are from regressions that control for the row A variables plus INFLOSS, INF HISTORY and LENGTH. Row $\mathrm{C}$ results are from regressions that control for the row B variables plus OPEN, CBI, OPEN*CBI and RIGHT. 